\title{
Legal Protection of Insurance Customers Due to Inverse Managers Involved in Corruption Crimes
}

\author{
Dede Supenti ${ }^{1}$, Suparno $^{2}$ \\ Borobudur University ${ }^{1,2}$ \\ \{dedeunbor@gmail.com ${ }^{1}$, suparno@borobudur.ac.id ${ }^{2}$ \}
}

\begin{abstract}
Corporate crime in Indonesia is very difficult for law enforcement. There is very difficulty especially reviewed from criminal accountability and the continuation of this corporation involved in business crimes, especially corruption crimes that are very detrimental to Indonesia's society. This paper uses normative juridical methods with qualitative approaches. In 2018 and 2019, PT Asuransi Jiwasraya (Persero) announced a default on many of its customers due to misplaced Investment funds that impacted the state's losses. Some customers who feel aggrieved have filed a lawsuit against PT Asuransi Jiwasraya (Persero). On the other hand, the attorney general's office has also established several suspects suspected of corruption and caused PT Asuransi Jiwasraya (Persero), which is a State-Owned Enterprise (SOE) suffered losses.
\end{abstract}

Keywords: Corruption; Customer, Insurance; Corporations

\section{Introduction}

As stipulated in the Republic of Indonesia's Constitution, the year 1945 Article 1 paragraph (3) states that Indonesia is a state of Law. In this case, the article's provisions are a constitutional basis that Indonesia is a country based on the Law. It also means that the Law is positioned as the only reference in the life of society, nation, and state (Syamsudin 2010). As a Law country, Indonesia wants the Law consistently to be enforced, respected, and obeyed by anyone without exception. It is intended to create security, order, welfare in the life of society and state. As a living individual, a man certainly has various interests and needs. To meet his needs and interests, man behaves and does so that his attitudes and actions do not harm others' interests and rights. The Law provides signs in the form of restrictions on conduct to achieve and fulfill these interests.

But to implement Indonesia as a legal country completely felt is still very difficult for now. The most common problem in the land of Law is the rise of humanity's crimes, one of which is corruption. In national development efforts in various fields, the community's aspirations to eradicate corruption and other irregular forms increase. In reality, the crime that causes losses for the country is substantial, impacting the onset of crises in various fields.

Corruption is a unique link that is regulated separately outside the Penal Code. In the process, handling corruption applies the principle that takes precedence or precedence over the settlement process. Under Article 25 of Law No. 20 of 2001 concerning Amendments to Law No. 31 of 1999 concerning the Eradication of Corruption. This case states that investigations, 
prosecutions, examinations in court hearings in corruption cases take precedence over other matters for immediate resolution (Corruption Eradication Commission (KPK) 2016). Sumarwani mentioned that there are several points prone to corruption in certain areas. These areas consist of: development projects that concern the interests of the community or the public, especially related to the implementation of land acquisition and labor-intensive, the second is developing projects for the public interest, such as the preparation of transmigration land, distribution of presidential funds, clean water projects, electricity and so on. The third field is the procurement of goods and services whose interests are much lower than the standard. The fourth is the field of credit distribution, both banking liquidity credit and investors credit, working capital credit, export credit, import credit, and so on. The fifth field is state financial income, especially related to tax collection activities, levying, import duty exemption, UNITED NATIONS, PN. So on, the sixth in the field of licensing or service to the community such as SUPP, SINK, driver's license, and so on, the last field is staffing that includes the acceptance and appointment of new employees.

Efforts to achieve and or safeguard the results of development are not only determined by the availability of adequate laws and regulations but must also be carried out in conjunction with consistent law enforcement for the establishment of legal supremacy in Indonesia. This is as mandated in the decree of MPR number IV/MPR/1999 chapter IV Sub A Point 3, which explains that upholding the Law and courage, supremacy of the Law and respecting human rights. In paying attention to this Mpr Tap, one aspect of the Law that needs attention is law enforcement against corruption. Given the corruption today is getting higher intesitasnya and therefore efforts to prevent and eradicate it, always have to be improved as one of the efforts to save the country's finances or economy. Eradication of corruption is certainly expected to meet and anticipate the development of public legal needs in order to prevent and eradicate more effectively any form of corruption crimes that are very detrimental not only to the state's finances or the state economy in particular, but also will be very detrimental to people's lives.

The problem of corruption is no longer a new problem in legal and economic issues for a country, this is because economic problems have existed since thousands of years ago, both in developed countries and in developing countries including Indonesia. Even the development of corruption problems in Indonesia today has been so severe and become a very extraordinary problem because it has spread and spread to all levels of society. If in the past corruption is often identified with officials or civil servants who have misused the state's finances, in its current development the problem of corruption has also involved members of the legislature and judiciary, bankers and conglomerates, as well as corporations as perpetrators of a corruption crime. This certainly makes a considerable dampa for the country's finances that are made a lot of losses. Even people at this time no longer feel ashamed to hold the predicate of corruption suspects so that corruption acts as if it has become something common or commonplace to do.

The perpetrators of the crimes referred to herein are every person who commits a crime of corruption or corruption that can cause financial or economic losses to the country, while what is meant by each person in accordance with the provisions of Paasal 1 point 3 of the Corruption Crime Act is an individual or including corporations. The element of whoever in this article clearly as the perpetrator of corruption crimes in the form of individuals or corporations that have harmed the state's finances (Syamsudin 2010). In general, corruption allegedly committed by corporations has been formulated in the Corruption Crime Act, where in its formulation in the article of criminal deliberation included in the Law Tipikor begins by using the phrase of the word "everyone", then in the second phrase followed 
by the use of the phrase one where everyone is interpreted as an individual and also includes a corporation.

In the Investment Manager company there are several important organs in the implementation of the company's business activities including directors, commissioners, shareholders, and investment managers. Investment managers in this regard have a very important role in determining the success of managing investor funds.

Investment managers are always an issue to be held accountable when investors in this case who deposit their funds to maximize profits suffer losses either because the investment manager is negligent in managing investor funds or the investment manager violates the provisions of the laws and regulations.

The Financial Services Authority as stipulated in Law No. 21 of 2011 concerning Financial Services Authority ("OJK") is an independent institution and free from interference from other parties, which has fiingsi, duties, and regulatory authority, supervision, examination, and investigation in the financial services sector. OJK was formed with the aim that all financial services activities are held regularly, fairly, transparently, and accountable, and able to realize a financial system that grows sustainably and stable, and is able to protect the interests of consumers and society. In other words, OJK can support the interests of the national financial services sector so as to increase national competitiveness. In addition, OJK is able to safeguard the national interest which includes human resources, management, control, and ownership of the financial services sector, while considering the positive aspects of globalization. In this case the role of OJK is needed in the field of supervision related to the role and function of investment manager companies.

Even based on Article 1 number 1 of the Law is also formulated the understanding of the corporation whether it is a legal entity or not a legal entity. Based on this everyone also including corporations can be qualified to be the subject of a crime of corruption. In fact, this is disputed in Article 20 of Law No. 31 of 1999 concerning Corruption Crimes where it is explained about corruption committed by the corporation of the fund or its administrators. There are 3 interesting things related to corruption that is carried out by the co-ordrasi, this happens by linking with the desire of the KPK to bring corruption cases before the court, namely the first KPK states that most cases of bribery in the act of corruption is committed by the corporation, secondly none of the corporations are punished in all corruption cases handled by kpk involving corporations, this happens because the corruption is handled only as a personal or individual, the three cases of corporate corruption are also involving politicians other than bureaucracy. This statement would like to confirm that there are other potential interests working in a corruption case committed by the corporation.

The revelation of the case of mismanagement of the business of PT Asuransi Jiwasraya (Jiwasraya) has captured the public's attention. Jiwasraya was established during the reign of the Dutch East Indies on December 31, 1859 and changed to PT. Asuransi Jiwasraya (persero) on August 21, 1984. In the course of jiwasraya business condition had improved in 2011 despite the impact of the economic crisis in 1998. However, the liquidity condition caused Jiwasraya to fail to pay js saving plan customer claims amounting to Rp. 802 Billion in October 2018 and reached RP. 12.4 trillion as of December 2019.

Jiwasraya's poor finances are due to companies buying second- and third-tier stocks near the close of the quarter or the close of the year to "beautify" financial statements. The Financial Review Board (BPK) found that the share price at which Jiwasraya invested always "jumped" ahead of the tuutp of the year and then the shares were sold again on January 2 of the following year. Because the shares are purchased below the market price, then in the yearend financial statements are recorded the results of jiwasraya profitable investments or 
pseudo-profits. But what really happened was that the company had already suffered losses. Jiwasraya's case continued to roll until on January 14, 2020 the attorney general's office (Kejagung) detained 5 people suspected of involvement in jiwasraya case, 3 of whom were former directors of Jiwasraya namely Hendrisman Rahim as former President Director, Harry Prasetyo as Former Finance Director, and Syamirwan Former Head of Investment and Finance Division. All three were charged with violating Article 2 and Article 3 of the Corruption Act.

The detention was carried out based on the results of an investigation by the Financial Management Agency (BPK) which found that there were alleged corporate crimes in the management of the company involving the board of directors, managers and other parties outside the company. In 2016 BPK has actually revealed 16 findings that identify violations of the Law, but only in June 2019 prosecutors began to investigate the case. This corporate crime is strongly suspected to be the cause of Jiwasraya's failure to pay customers a total of Rp. 802 billion as of October 2018 and to Rp. 12.4 trillion as of December 2019. This condition is troubling for 7.7 million customers.

\section{Methods}

The research method used in this writing is a normative juridical research method using qualitative research approach. Normative juridical research is a type of research that is commonly done in legal science development activities or commonly known as legal dogmatics. Normative juridical research is a method of research by studying books, laws and regulations and other supporting documents related to research so that it can be addressed the relationship between positive laws and principles prevailing in society.

Normative juridical research methods using qualitative research approach include inventory activities, explaining, interpreting, systematizing and also evaluating the overall positive laws applicable in a particular society or country with concepts (understandings), categories, theories, classifications, and methods that are formed and developed specifically to perform all these activities, all of which are directed to prepare efforts to find juridical solutions to legal problems (micro and macro) that may occur in society. Normative juridical research is directly directed to offer an alternative juridical solution to concrete legal issues. The alternative settlement offered was formulated in the form of a legal ruling called also a legal proposition. This legal proposition contains the determination of the rights and obligations of certain legal subjects; meaning: contains the rule of Law.

\section{Discussion}

\subsection{Accountability of Investment Manager Companies Involved in Corruption Crimes}

The revelation of the case of mismanagement of the business of PT Asuransi Jiwasraya (Jiwasraya) has captured the public's attention. Jiwasraya was established during the reign of the Indies of Belnada on December 31, 1859 and became PT Asuransi Jiwasraya (Persero) on August 21, 1984. In the course of the financial condition Jiwasraya had improved in 2011 although the company also received the effects of the monetary crisis in 1998. However, the lack of liquidity caused jiwasraya to fail to pay js saving plan customer claims amounting to Rp.802 billion in October 2018 and reached Rp. 12.4 trillion in December 2019. Jiwasraya's 
poor finances due to the company buying second and third tier stocks near the close of the year or close of the year, this is done to make the form of financial statements belonging to Jiwasraya experienced significant, this is because with the addition of investments in the financial statements purchased near the close of the year and then sold on January 2 of the following year make the year-end financial statements will be recorded profitable investment results. But in jiwasraya's case they did not realize that the company had suffered losses by the time they made the purchase of second and third tier shares in the period leading up to the close of the year.

The financial condition of Jiwasraya company has actually started to deteriorate since 2002 due to the economic crisis. Until finally can not afford to pay the policy of the customers. The following is the chronology of jiwasraya financial condition from 2002 to 2019.

In accordance with Article 142 paragraph (1) letter e of Law No. 40 of 2007 concerning Limited Liability Companies and looking at the current financial condition of Jiwasraya, the company can be disbanded in Jiwasraya (Ningrum 2018). The dissolution of the company occurred because the company's assets that have been declared bankrupt are in a state of insolvency, as stipulated in Law No. 37 of 2004 concerning bankruptcy and suspension of debt repayment obligations. The financial condition of jiwasraya in insolvency has occurred since 2002. So that the management of jiwasraya can actually declare bankruptcy so that it can be delayed debt payer obligations. Another alternative solution is if the government will save Jiwasraya.

Jiwasraya rescue that will be done by the government can be done in three ways, the first is by privatization, bailout (bailout) in the form of state capital investment (PMN) from the state budget, and the establishment of state-owned insurance holding. Privatization is carried out while keeping the government as the majority shareholder or shareholder above $50 \%$ with the need for Rp. 32 trillion of funds to meet the risk based capital (RBC) regulated by OJK by $120 \%$. However, to privatize jiwasraya financial condition must be in good health, so that it has a high selling value to meet the needs of large enough funds.

The second is the effort to save Jiwasraya by bailout with PMN. Where in this case it is necessary to consider the current state financial condition (APBN). But with all the problems that occur in Indonesia today where the problem of covid19 that causes spending a lot of expenditures spent by the state, while the condition of state revenue from taxes has not been optimal. The government still needs funds outside the state budget to overcome the Covid19 disaster. So if Jiwasraya makes a settlement through the bailout PMN needs to include alternaif solution source of funds, whether through government bonds or loans from abroad. Third is through the holding of state-owned insurance, if this is done then it must take into account the ability of the state-owned enterprises to absorb jiwasraya bonds around Rp. 4-5 trillion. This obscures the main purpose of the holding itself which is to increase competitiveness.

In addition, the legal protection measures that can be strengthened in this case consist of two things, the first is the legal protection of the criminal aspect, which by criminally processing the parties that cause state losses in the body jiwasraya. Currently kejagung has set several parties as suspects, kejagung is also working with PPATK to trace assets owned by Jiwasraya as well as looking for evidence related to money laundering crimes. The use of the TPPU article will greatly help the development of this case so that the suspects can be criminally charged in the form of surrogate money. KPK can be involved in this case especially if it involves law enforcement officials and state administration, troubling the community and causing a minimum loss of Rp. 1 billion. 
The third is the legal protection of the civil aspect. This protection can be done by du event i.e. ordinary civil lawsuits or bankruptcy. Civil legal protection can be provided by the judge handling the case. This lawsuit can be filed with jiwasraya's directors, commissioners, and shareholders if it is proven that they have taken actions that harm the company. Currently some customers have filed a default lawsuit against Jiwasraya, while bankruptcy can be filed by the customers only settlement through bankruptcy is very detrimental to insurance customers because in practice the position of the customer only as a concurrent creditor who will get the need after the wages of separatist creditor workers and preferential kredtor.

\subsection{OJK's Authority in Supervision of Investment Manager Companies}

The event of default of the policy that befell the insurance company PT. Jiwasraya Persero certainly can not be separated from the role of Financial Services Otoitas (OJK) as an institution in charge of supervising banking and non-banking financial services institutions in Indonesia, especially against insurance companies. Many parties questioned how to adjust the OJK especially by the House of Representatives in this case. According to the statement submitted by the chairman of the board of commissioners OJK stated that the case of policy default by Jiwasraya has been included in the supervision of OJK since 2006 when the authority was still named Bapepam-LK. OJK also until now continues to look for exit jaan related to the issue.

OJK also claims that it has performed its function as a supervisory agency in this case. The OJK agrees that efforts to heal Jiwasraya are not carried out by the OJK, but by the main shareholders, namely the ministry of SOEs. OJK plays a role to facilitate the recovery efforts proposed by the owners of the company. OJK also provides warnings to the ministry of SOEs and Jiwasraya in conducting health in order to be advanced as much as possible. This is done so that the customer's rights can be fulfilled immediately. Based on the information provided by the OJK, the OJK has provided maximum supervision measures to resolve this issue. OJK itself has been in good communication with customers regarding receiving their complaints to the ministry of SOEs to accelerate rescue and recovery measures in the management of the company and its finances. The reason why it is rare taken oelh OJK seems not to be berjala because it is less see how the authority owned by the OJK. In the case of Jiwasraya OJK as a facilitator that should facilitate the recovery efforts conducted by the company, not be the executor who carries out the healing process, because it is the authority owned by the shareholders and in this case the ministry of SOEs.

The Financial Services Authority (OJK) as a supervisory institution and also as a regulator against financial services institutions in Indonesia must certainly have a role when there are problems that befall the financial services institutions, both banking and non-banking in Indonesia. Similarly, in the case of default of the policy experienced by PT. Asuransi Jiwasraya Persero, OJK in this case claims to have played a role in the process of resolving this case. As stated by the chairman of the supervisory board of OJK Wimboh Santoso, that OJK has made several scenarios of saving PT. Asuransi Jiwasraya Persero. "To create a scenario how to overcome cash flow to pay all these customer claims. We all know that it's not easy, but there are still scenarios.

The first scenario that will be made is a short-term solution, namely the establishment of a subsidiary namely PT. Jiwasraya Putra. The Company in the form of this subsidiary has been given a concession to guarantee insurance from several SOEs that have cooperated previously with jiwasraya companies. namely PT Bank Tabungan Negara (Persero) Tbk, PT Pegadaian (Persero), PT Kereta Api Indonesia (Persero), and PT Telkomsel. In addition, the existence of 
this subsidiary is also required to attract investors, with the aim of helping fund policy claim obligations by PT. Asuransi Jiwasraya Persero which is due through Top-Up Cashflow. PT Jiwasraya Putra will later utilize this BUMN cooperation to sell insurance products by utilizing customer-based access and distribution networks in the four companies.

Then the second scenario is the solution for the long term. He said it was still being discussed by stakeholders. "If the short term is resolved in that way, in the long medium term there should be a program on how to strengthen Jiwasraya's business.102 As it is known that Jiwasraya needs funds of around Rp32.89 trillion in order to achieve a Risk Based Capital (RBC) ratio of at least 120 percent. In general, $\mathrm{RBC}$ is a measurement of the financial health level of an insurance company, provided that the OJK regulates a minimum rbc limit of 120 percent.

The Financial Services Authority was formed with the aim that all financial services activities in the financial services sector are held regularly, fairly, transparently, and accountably, and able to realize a financial system that grows sustainably and stablely, and is able to protect the interests of consumers and society. With this goal, OJK is expected to support the interests of the national financial services sector so as to increase national competitiveness. In addition, OJK should be able to safeguard the national interest, among others, including human resources, management, control, and ownership in the financial services sector, while considering the positive aspects of globalization. In line with the above, in this case OJK has tried to carry out its functions and authorities in accordance with that purpose. although it must be recognized that in its journey, the role performed by the OJK in order to save in this case is not perfect, because in fact OJK can conduct a deeper examination of insurance products issued by PT. Asuransi Jiwasraya Persero as a form of carrying out the supervisory function. but at least OJK has shown good faith to play an active role in this case, with the presence of such designed scenarios and other actions that have been described before.

\section{Conclusion}

Jiwasraya's case is fraught with legal problems, there are at least more than 8 rules that are violated. The prosecution has harmed the customer so that law enforcement officials must rush to legal protection by requesting criminal, civil and administrative and ethical responsibility from the perpetrators of this case. The large number of parties involved and the various rules violated make the legal settlement process against this case can take a very long time. Therefore, the legal protection process can be done simultaneously. The legal settlement cannot be ignored because it is an important part of the protection of the state huku against the community in order to create a sense of security. In addition, the Financial Services Authority was formed with the aim that the overall financial services activities in the financial services sector are held regularly, fairly, transparently, and accountable, and able to realize a financial system that grows sustainably and stable, and is able to protect the interests of consumers and society. With this goal, OJK is expected to support the interests of the national financial services sector so as to increase national competitiveness. In addition, OJK should be able to safeguard the national interest, among others, including human resources, management, control, and ownership in the financial services sector, while considering the positive aspects of globalization. In line with the above, in this case OJK has tried to carry out its functions and authorities in accordance with that purpose. although it must be recognized that in its journey, the role performed by the OJK in order to save in this case is not perfect, because in fact OJK 
can conduct a deeper examination of insurance products issued by PT. Asuransi Jiwasraya Persero as a form of carrying out the supervisory function. but at least OJK has shown good faith to play an active role in this case, with the presence of such designed scenarios and other actions that have been described before.

\section{References}

[1] Hasan, Sabri, and Aditya Halim Perdana Kusuma Putra. 2018. "Loyalitas Pasien Rumah Sakit Pemerintah: Ditinjau Dari Perspektif." Jurnal Manajemen Indonesia 18(3): 184-96.

[2] Sibarani, Sabungan. 2017. "Aspek Perlindungan Hukum Pasien Korban Malpraktik Dilihat Dari Sudut Pandang Hukum di Indonesia." Justitia et Pax 33(1): 1-22.

[3] Azhary, H Muhammad Tahir. 2015. Beberapa Aspek Hukum Tata Negara, Hukum Pidana Dan Hukum Islam. Prenada Media.

[4] Tutik, Titik Triwulan, and Shita Febriana. 2010. Perlindungan Hukum Bagi Pasien. Prestasi Pustaka Publisher.

[5] Asram AT Jadda. 2017. "Perlindungan Hukum Terhadap Pasien Sebagai Konsumen Jasa Pelayanan Kesehatan." Madani Legal Review 1(1): 1-28.

[6] Nurdin, M. 2015. "Perlindungan Hukum Terhadap Pasien Atas Korban Malpraktek Kedokteran." Jurnal Hukum Samudra Keadilan 10(1): 92-109. https://media.neliti.com/media/publications/240395-perlindungan-hukum-terhadappasien-atas-97f6abae.pdf.

[7] Sandiata, Oleh Stefany B. 2013. "PERLINDUNGAN HUKUM HAK MENDAPATKAN PELAYANAN KESEHATAN Di RUMAH SAKIT PEMERINTAH." Lex Administratum 1(2): 187-94.

[8] Supriyanto, Eko Eddya. 2020. Eksistensi Nilai-Nilai Pancasila Dalam Kebijakan Ekonomi Indonesia. 1st ed. Malang: Literasi Nusantara. 